\title{
IMPLEMENTASI DISCOVERY LEARNING UNTUK MENINGKATKAN KETERAMPILAN DASAR PROSES SAINS SISWA SMA
}

\author{
Rahmat Rizal', Irwan Muhammad Ridwan' \\ 1. Universitas Siliwangi \\ 2. Universitas Siliwangi \\ E-mail: rahmatrizal@unsil.ac.id
}

\begin{abstract}
ABSTRAK
Telah dilakukan penelitian mengenai implementasi discovery learning untuk meningkatkan keterampilan dasar proses sains. Discovery learning yang diterapkan dalam penelitian ini merupakan sebuah pendekatan paling sederhana dari level pembelajaran inquiry dan dianggap paling layak bagi peserta didik yang belum terbiasa dengan kegiatan inquiry. Keterampilan dasar proses sains yang diteliti meliputi keterampilan mengamati, mengukur, mengkomunikasikan, dan membuat kesimpulan. Penelitian ini menggunakan metode quasi experiment dengan Randomized Pretest-Postest Control Group Design. Hasil uji statistik menunjukkan bahwa pembelajaran pada kelas eksperimen lebih baik dalam keterampilan dasar proses sains dibandingkan dengan pembelajaran pada kelas kontrol. N-gain pemahaman konsep pada kelas eksperimen berada pada kategori tinggi dengan komposisi keterampilan mengamati $(0,85)$, mengukur $(0,79)$, mengkomunikasikan $(0,75)$, dan membuat kesimpulan $(0,84)$. Sedangkan $\mathrm{N}$-gain pada kelas kontrol berada pada kategori sedang dengan komposisi keterampilan mengamati $(0,61)$, mengukur $(0,72)$, mengkomunikasikan $(0,45)$ dan membuat kesimpulan $(0,64)$.
\end{abstract}

Kata kunci: discovery learning, keterampilan dasar proses sains.

\begin{abstract}
Research has been conducted on the implementation of discovery learning to improve the basic skilss of science process. Discovery learning applied in this study is the simplest approach of the inquiry learning level and is considered as the most appropriate for students who are not familiar with inquiry activities. The basic skills of the science process studied include the skill of observing, measuring, communicating, and making conclusions. This study uses a quasi-experimental method with Randomized Pretest-Posttest Control Group Design. The results of statistical tests show that learning in the experimental class is better in improving the basic of the science process skills compared in the control class. $N$-gain basic of science process skills in the experimental class is in the high category with the composition of observing skills (0.85), measuring (0.79), communicating (0.75), and making conclusions (0.84). Whereas $N$-gain in the ontrol class was in the moderate category with the composition of observing skill (0.61), measuring (0.72), communicating (0.45) and making conclusions (0.64).
\end{abstract}

Keywords: discovery learning, basic skills of science process.

Received: 23 November 2018 ; Accepted: 1 Februari 2019 ; Published: 4 Februari 2019 


\section{PENDAHULUAN (CAMBRIA, ALL CAPS, 12 PT, BOLD)}

Pendidikan IPA menekankan pada pengalaman langsung siswa dalam memahami fenomena alam yang terjadi di sekitar mereka untuk menghasilkan pengetahuan yang bermakna dan melatihkan berbagai kemampuan dan keterampilan (Direktorat Tenaga Kependidikan, 2008). Hal ini mengarahkan bahwa pembelajaran IPA yang dilakukan memiliki fungsi untuk membimbing siswa menguasai pengetahuan melalui proses penemuan oleh siswa sendiri melalui pengalaman-pengalaman selama pembelajaran berlangsung. Dengan demikian pengetahuan yang diperoleh siswa menjadi lebih bermakna tanpa mengabaikan sejumlah keterampilan yang bisa dilatihkan melalui kegiatan pembelajaran.

Kegiatan pembelajaran IPA, termasuk di dalamnya fisika, sangat memperhatikan bagaimana proses pembelajaran terjadi sebagai bentuk pembiasaan dan pelatihan keterampilan tertentu. Hal ini sejalan dengan tujuan pembelajaran fisika yang telah di tetapkan oleh Badan Standar Nasional Pendidikan (Badan Standar Nasional PendidikaN, 2006). Secara spesifik salah satu tujuan pembelajaran fisika yaitu agar peserta didik memiliki sejumlah keterampilan proses sains yang dilatihkan melalui kegiatan percobaan. Adapun keterampilan tersebut meliputi keterampilan dalam merumuskan masalah, mengajukan hipotesis, merancang dan merakit instrumen, mengumpulkan, mengolah, dan menafsirkan data serta mengkomunikasikannya secara lisan dan tertulis.

Keterampilan proses merupakan semua keterampilan yang diperlukan untuk memperoleh, mengembangkan, dan menerapkan konsep-konsep prinsip-prinsip, hukum-hukum dan teori-teori IPA, baik berupa keterampilan intelektual, keterampilan fisik, maupun keterampilan sosial (Nuryani, R., dkk, 2005). Rustaman menyebutkan bahwa keterampilan proses sain terdiri dari sembilan poin keterampilan yang terdiri dari sembilan keterampilan seperti yang ditunjukkan pada Tabel 1.

Tabel 1. Keterampilan Proses Sains

\begin{tabular}{|c|c|c|}
\hline No & Jenis & Sub keterampilan \\
\hline 1 & Mengamati & $\begin{array}{l}\text { a. Menggunakan indera } \\
\text { b. Mengumpulkan fakta } \\
\text { yang relevan } \\
\text { c. Mencari persamaan } \\
\text { dan perbedaan }\end{array}$ \\
\hline 2 & $\begin{array}{l}\text { Menafsirkan } \\
\text { pengamatan }\end{array}$ & $\begin{array}{l}\text { a. Mencatat pengamatan } \\
\text { secara terpisah } \\
\text { b. Menghubungkan hasil- } \\
\text { hasil pengamatan } \\
\text { c. Menemukan suatu } \\
\text { pola dalam satu } \\
\text { pengamatan } \\
\text { d. Menarik kesimpulan }\end{array}$ \\
\hline 3 & Mengelompokkan & $\begin{array}{l}\text { a. Mencari perbedaan } \\
\text { b. Mengontraskan ciri- } \\
\quad \text { ciri } \\
\text { c. Mencari kesamaan } \\
\text { d. Membandingkan } \\
\text { e. Mencari dasar } \\
\text { penggolongan }\end{array}$ \\
\hline 4 & Meramalkan & $\begin{array}{l}\text { a. Mengajukan perkiraan } \\
\text { tentang sesuatu yang } \\
\text { belum terjadi } \\
\text { berdasarkan } \\
\text { kecenderungan yang } \\
\text { sudah ada }\end{array}$ \\
\hline 5 & Berkomunikasi & $\begin{array}{l}\text { a. Menyusun dan } \\
\text { menyampaikan } \\
\text { laporan secara } \\
\text { sistematis dan jelas } \\
\text { b. Menjelaskan hasil } \\
\text { percobaan dan } \\
\text { pengamatan } \\
\text { c. Menggambarkan data } \\
\text { dengan grafik, tabel, } \\
\text { atau diagram. }\end{array}$ \\
\hline 6 & Berhipotesis & $\begin{array}{l}\text { a. Menyatakan } \\
\text { hubungan antara dua } \\
\text { variabel } \\
\text { b. Mengajukan perkiraan }\end{array}$ \\
\hline
\end{tabular}

Jurnal JoTaLP 4, 1 (2019): 01-10 


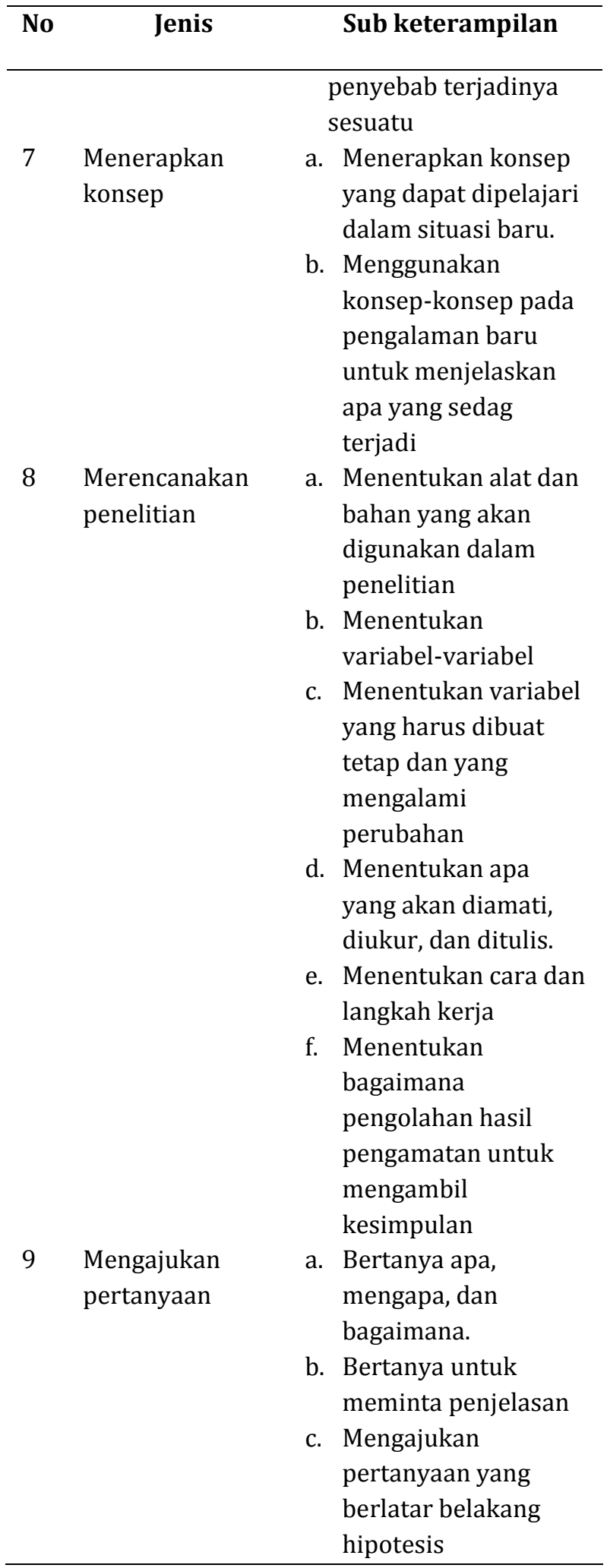

Rezba mengklasifikasi keterampilan proses sains dalam dua level keterampilan yang terdiri dari keterampilan dasar proses sains dan keterampilan sains terintegrasi seperti yang ditunjukkan pada Tabel 2 dan Tabel 3 (Rezba, R., Sprague, J., Fiel, C., 2005)

Tabel 2. Keterampilan Dasar Proses Sains

$\begin{array}{ccc}\mathbf{N} & \text { Kete- } & \text { Sub Keterampilan } \\ \mathbf{0} & \text { rampilan } & \end{array}$

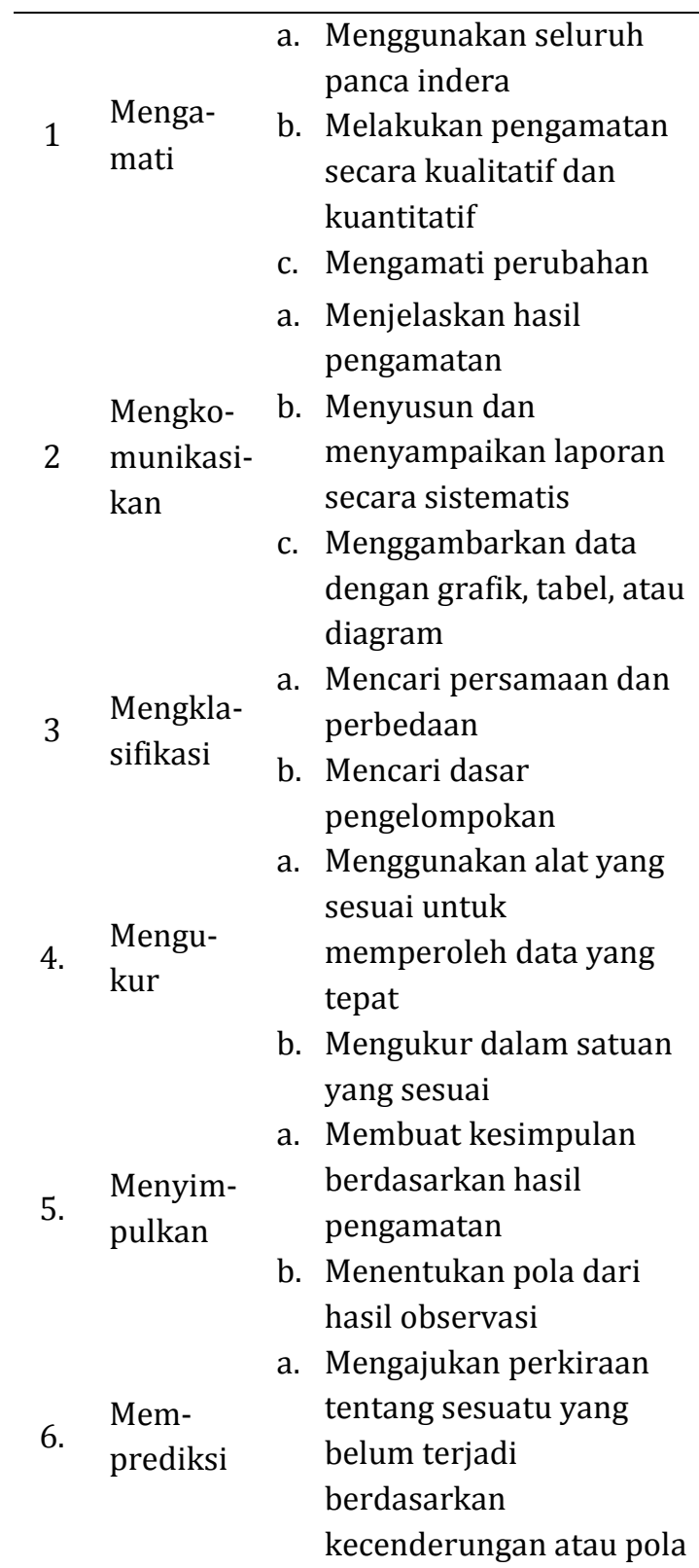




\begin{tabular}{ccl}
\hline $\begin{array}{c}\text { N } \\
\text { o }\end{array}$ & $\begin{array}{c}\text { Kete- } \\
\text { rampilan }\end{array}$ & Sub Keterampilan \\
\hline & & yang sudah ada. \\
& b. & $\begin{array}{l}\text { Menggunakan pola-pola } \\
\text { hasil pengamatan }\end{array}$ \\
\hline
\end{tabular}

Tabel 3. Keterampilan Proses Sains Terintegrasi

\begin{tabular}{|c|c|c|}
\hline No & $\begin{array}{c}\begin{array}{c}\text { Keteram- } \\
\text { pilan }\end{array} \\
\end{array}$ & $\begin{array}{c}\text { Sub keterampilan } \\
\text { proses sains }\end{array}$ \\
\hline 1 & $\begin{array}{l}\text { Mengidentifikasi } \\
\text { variabel }\end{array}$ & $\begin{array}{l}\text { a. Mengidentifikasi } \\
\text { variabel yang } \\
\text { penting dalam } \\
\text { investigasi } \\
\text { b. Membedakan } \\
\text { variabel bebas } \\
\text { dan variabel } \\
\text { terikat }\end{array}$ \\
\hline 2 & $\begin{array}{l}\text { Membuat tabel } \\
\text { data }\end{array}$ & $\begin{array}{l}\text { a. Membuat tabel } \\
\text { yang sesuai } \\
\text { dengan data } \\
\text { b. Memodifikasi } \\
\text { tabel untuk data } \\
\text { berulang }\end{array}$ \\
\hline 3 & $\begin{array}{l}\text { Menggambarkan } \\
\text { grafik }\end{array}$ & $\begin{array}{l}\text { a. Memberikan label } \\
\text { pada sumbu x dan } \\
\text { sumbu y } \\
\text { b. Menentukan } \\
\text { rentang skala } \\
\text { grafik pada } \\
\text { masing-masing } \\
\text { sumbu } \\
\text { c. Membuat plot } \\
\text { data pada grafik }\end{array}$ \\
\hline 4 & $\begin{array}{l}\text { Menjelaskan } \\
\text { hubungan antar } \\
\text { variabel }\end{array}$ & $\begin{aligned} & \text { a. } \text { Menjelaskan } \\
& \text { hubungan antar } \\
& \text { variabel dalam } \\
& \text { grafik } \\
& \text { b. } \\
& \text { Menggambarkan } \\
& \text { kecenderungan } \\
& \text { grafik yang sesuai } \\
& \text { dengan poin pada } \\
& \text { grafik }\end{aligned}$ \\
\hline 5 & $\begin{array}{l}\text { Mengumpulkan } \\
\text { dan } \\
\text { menganalisis } \\
\text { data }\end{array}$ & $\begin{array}{l}\text { a. Mengawali } \\
\text { investigasi } \\
\text { dengan } \\
\text { pertanyaan } \\
\text { "mengapa?" } \\
\text { b. Mengumpulkan } \\
\text { data yang }\end{array}$ \\
\hline
\end{tabular}

\begin{tabular}{|c|c|c|}
\hline No & $\begin{array}{l}\text { Keteram- } \\
\text { pilan }\end{array}$ & $\begin{array}{l}\text { Sub keterampilan } \\
\text { proses sains }\end{array}$ \\
\hline \multirow{3}{*}{6} & & $\begin{array}{l}\text { diperoleh dari } \\
\text { pengamatan, } \\
\text { survey, dan } \\
\text { eksperimen }\end{array}$ \\
\hline & $\begin{array}{l}\text { Menganalisis } \\
\text { investigasi }\end{array}$ & $\begin{array}{l}\text { a. Mengidentifikasi } \\
\text { variabel bebas, } \\
\text { variabel terikat, } \\
\text { dan variabel } \\
\text { kontrol }\end{array}$ \\
\hline & & $\begin{array}{l}\text { b. Mengidentifikasi } \\
\text { hipotesis yang } \\
\text { sedang diselidiki }\end{array}$ \\
\hline 7 & $\begin{array}{l}\text { Membuat } \\
\text { hipotesis }\end{array}$ & $\begin{array}{l}\text { a. Menyatakan } \\
\text { hubungan } \\
\text { variabel yang } \\
\text { akan diuji }\end{array}$ \\
\hline & & $\begin{array}{l}\text { b. Mengajukan } \\
\text { perkiraan } \\
\text { penyebab sesuatu } \\
\text { terjadi }\end{array}$ \\
\hline 8 & $\begin{array}{l}\text { Mendefinisikan } \\
\text { variabel secara } \\
\text { operasional }\end{array}$ & $\begin{array}{l}\text { a. Menentukan cara } \\
\text { mengukur } \\
\text { variabel dalam } \\
\text { investigasi }\end{array}$ \\
\hline 9 & $\begin{array}{l}\text { Mendesain } \\
\text { eksperimen }\end{array}$ & $\begin{array}{l}\text { a. Menentukan alat } \\
\text { dan bahan yang } \\
\text { akan digunakan }\end{array}$ \\
\hline & & $\begin{aligned} \text { b. Menentukan cara } \\
\text { dan langkah kerja } \\
\text { c. Menentukan cara } \\
\text { mengolah dan } \\
\text { menganalisis data }\end{aligned}$ \\
\hline 10 & $\begin{array}{l}\text { Melakukan } \\
\text { eksperimen }\end{array}$ & $\begin{array}{l}\text { a. Melakukan } \\
\text { investigasi yang } \\
\text { sesuai dengan } \\
\text { masalah yang } \\
\text { telah } \\
\text { diidentifikasi atau } \\
\text { dipelajari } \\
\end{array}$ \\
\hline
\end{tabular}

Mengingat pentingnya keterampilan proses sains untuk dilatihkan kepada siswa melalui kegiatan pembelajaran fisika, maka diperlukan langkah pembelajaran yang efektif dan melibatkan siswa secara aktif untuk melakukan proses sebagaimana para ilmuwan melakukan kegiatan ilmiah. Salah satu bentuk pembelajaran fisika 
yang dapat melatihkan keterampilan proses sains diantaranya adalah pembelajaran inquiri (Rizal, R., 2017). Pembelajaran inquiri memberikan ruang yang terbuka kepada peserta didik untuk dapat melaksanakan aktivitas ilmuwan yang tercakup dalam keterampilan proses sains.

Untuk menghindari kebingungan siswa dalam mengikuti kegiatan pembelajaran inquiri, maka Wenning memperkenalkan enam level inquiry yang terdiri dari discovery learning, interacive demonstration, inquiry lesson, inquiry lab, realworld application dan hypothetical inquiry (Wenning, C., 2011). Enam level inkuiri ini perlu dilakukan secara berjenjang mulai dari yang paling sederhana, karena peserta didik yang belum terbiasa dengan inquiri akan mengalami kebingungan terhadap apa yang akan dilaksanakan dalam pembelajaran dan berdampak pada ketidakefektifan dan kebermaknaaan pembelajaran.

\begin{tabular}{|c|c|c|c|c|c|}
\hline $\begin{array}{l}\text { Discovery } \\
\text { learning }\end{array}$ & $\begin{array}{c}\text { Demonstrasi } \\
\text { interaktif }\end{array}$ & $\begin{array}{l}\text { Inquiry } \\
\text { lesson }\end{array}$ & $\begin{array}{l}\text { Inquiry } \\
\text { Lab }\end{array}$ & $\begin{array}{l}\text { Real world } \\
\text { applications }\end{array}$ & $\begin{array}{c}\text { Hypothetical } \\
\text { inquiry }\end{array}$ \\
\hline Rendah & & \multicolumn{2}{|c|}{$\begin{array}{l}\text { Kecerdasan } \\
\text { intelelktual }\end{array}$} & & $\rightarrow$ Tinggi \\
\hline Guru & & & & & $\rightarrow$ Siswa \\
\hline
\end{tabular}

Gambar 1. Hirarki pembelajaran inquiri Rizal menyebutkan bahwa discovery learning merupakan pembelajaran inquiry yang paling sederhana dan layak digunakan untuk membelajarkan peserta didik yang belum terbiasa dengan pembelajaran inquiri (Rizal, R., 2018). Hal ini diperkuat oleh pemerintah juga telah menyampaikan saran untuk dapat membelajarkan IPA dengan mengedepankan peningkatan kemampuan ilmiah yang salah satunya adalah dengan menggunakan discovery learning (Kosasih, 2014).

Pembelajaran discovery learning dapat dilakukan dengan mengikuti tiga langkah sistematis sebagai berikut:

a. Mengumpulkan pengalaman siswa.
Pada tahap ini guru mengajukan pertanyaan untuk mengumpulkan pengalaman siswa dalam kehidupan sehari-hari, tentang apa yang pernah mereka lihat, dengar, rasakan, dan mereka cium melalui sebuah fenomena yang berhubungan dengan konsep yang akan dijelaskan. Hal ini ditujukan agar konsep yang mereka dapatkan akan lebih berkesan.

b. Membangun konsep.

Pada tahap ini guru mengajukan berbagai pertanyaan untuk membimbing siswa mengetahui dan menemukan konsep sebagai penyebab terjadinya fenomena atau pengalaman yang mereka alami.

c. Menarik kesimpulan.

Guru membimbing siswa melalui pertanyaan arahan untuk menerapkan konsep yang telah ditemukan dalam membuat sebuah kesimpulan dari pengalaman yang dialami oleh siswa.

Bruner menganggap bahwa belajar penemuan sesuai dengan pencarian pengetahuan secara aktif oleh manusia, dan dengan sendirinya memberikan hasil yang paling baik (Dahar, R., 1989). Oleh karena itu, pada tahap awal kegiatan discovery learning ini guru dapat memanfaatkan pengetahuan siswa untuk menciptakan masalah. Jika tidak ada permasalahan yang dikemukakan, kegiatan awal dapat diganti dengan sebuah percobaan sederhana yang kemudian diangkat menjadi permasalahan. Permasalahan tersebut dipecahkan oleh siswa dengan mendapatkan bantuan dari guru berupa pertanyaanpertanyaan panduan sampai diperoleh kesimpulan.

\section{METODE PENELITIAN}

Penelitian ini dilakukan dengan menggunakan metode eksperimen semu dengan desain randomized pretest-postest control group (Sukmadinata, S., 2009). Populasi penelitian ini adalah kelas $\mathrm{X}$ di salah satu SMA negeri di kota 
Bandung dengan sampel penelitian yang terdiri dari dua kelas. Satu kelas digunakan sebagai kelas eksperimen yang diterapkan pendekatan discovery learning dan satu kelas lainnnya digunakan sebagai kelas kontrol yang menerapkan pembelajaran konvensional.

Instrumen yang digunakan dalam penelitian ini adalah tes tertulis keterampilan proses sains yang diberikan pada saat pretest dan posttest. Instrumen tersebut telah mendapat judgement beberapa pakar untuk memastikan validitas setiap soal yang digunakan dan telah diujicobakan. Untuk menguji realibilitas instrumen digunakan uji korelasi produk momen dengan persamaan (Arikunto, S., 2003).

$r_{x y}=\frac{N \sum X Y-\left(\sum X\right)\left(\sum Y\right)}{\sqrt{\left(N \sum X^{2}-\left(\sum X\right)^{2}\right)\left(N \sum Y^{2}-\left(\sum Y\right)^{2}\right)}}$

Keterangan :

rxy = koefisien korelasi antara variabel X dan Y, skor test dan retest yang dikorelasikan.

$\mathrm{X}=$ skor test.

$\mathrm{Y}=$ skor retest.

Dari hasil ujicoba instrumen menggunakan korelasi produk momen diperoleh nilai reliabilitas sebesar 0,92 dengan kategori sangat tinggi.

Untuk melihat peningkatan keterampilan proses sains siswa, dilakukan pengolahan data menggunakan rata-rata $\mathrm{N}$-gain yang dikemukakan oleh Hake dengan menggunakan persamaan sebagai berikut (Hake, R., 2002)

$$
<g>=\frac{<\% S_{p o s t}>-<\% S_{p r e}>}{100-<\% S_{p r e}>}
$$

Interpretasi dari hasil perhitungan $\mathrm{N}$-gain dinyatakan dalam Tabel 4.
Untuk mengetahui perlakuan yang lebih baik dalam meningkatkan pemahaman konsep listrik dinamis di kelas kontrol dan kelas eksperimen juga digunakan pengujian hipotesis secara statistik. Langkah pegujian secara ststistik dilakukan dalam beberapa tahapan. Pertama, uji normalitas data dengan uji Kolmogorov-Smirnov. Kedua, uji homogenitas dengan menggunakan uji Lavene. Ketiga, uji t terhadap hipotesis penelitian yang berbunyi pembelajaran di kelas eksperimen dengan mengimplementasikan discovery learning dapat lebih meningkatkan pemahaman konsep listrik dinamis siswa dibandingkan dengan pembelajaran di kelas kontrol $\left(\mu_{\mathrm{x}}>\mu_{\mathrm{y}}\right)$

\section{HASIL DAN PEMBAHASAN}

Rata-rata N-gain pada kelas eksperimen dan kelas kontrol dalam penelitian ini dapat dilihat pada Gambar 2.

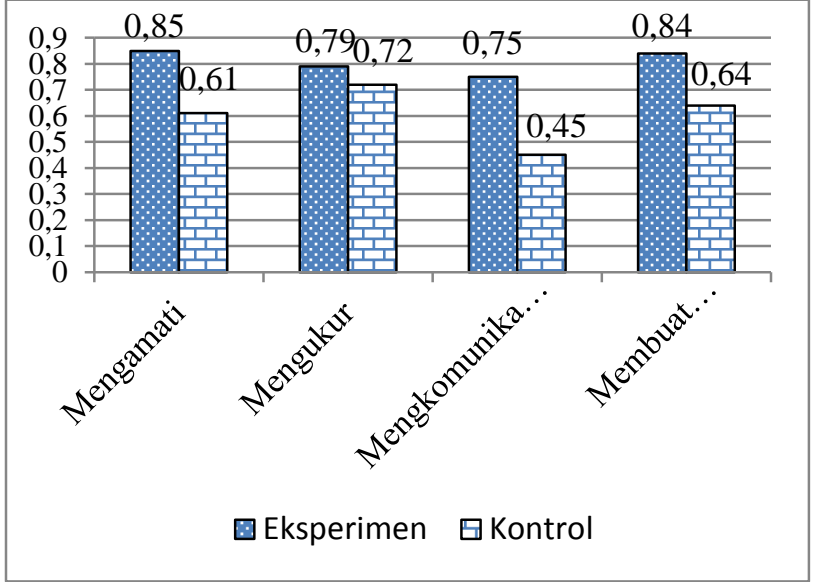

Gambar 2. Keterampilan dasar proses sains siswa

Dari Gambar 2 bisa kita lihat bahwa untuk setiap keterampilan dasar proses sains di kelas eksperimen menunjukkan $\mathrm{N}$-gain yang berada pada kategori tinggi, sedangkan pada kelas kontrol N-gain yang dihasilkan berada pada kategori sedang. Dengan kata lain, pembelajaran fisika menggunakan discovery learning dapat meningkatkan keterampilan dasar proses sains menjadi lebih baik (Yusuf, M., Ratna, A., 2015; Nenchi, M., Swistoro, E., Risdianto, E., 2017). 
Keunggulan discovery learning dalam meningkatkan keterampilan dasar proses sains juga diperkuat dengan hasil pengujian data secara statistik seperti yang ditunjukkan pada Tabel 5, Tabel 6, dan Tabel 7.

Tabel 5. Uji Kolmogorov-Smirnov terhadap $\mathrm{N}$-gain keterampilan dasar proses sains pada kelas eksperimen dan kelas kontrol

\begin{tabular}{cccc}
\hline \multirow{2}{*}{ kelompok } & \multicolumn{3}{c}{ Kolmogorov-Smirnov } \\
& Statistic & $\mathrm{df}$ & Sig. \\
eksperimen & .102 & 37 & $.200^{*}$ \\
kontrol & .102 & 37 & $.200^{*}$ \\
\hline
\end{tabular}

Tabel 6. Uji Lavene terhadap N-gain keterampilan dasar proses sains pada kelas eksperimen dan kelas kontrol

Levene's Test for Equality of Variances
$\mathrm{F}$
Sig.
1.280
0.262

Tabel 7. Uji t dalam melakukan uji hipotesis penelitian

\begin{tabular}{ccccc}
\hline T & df & $\begin{array}{c}\text { Sig. (2- } \\
\text { tailed) }\end{array}$ & \multicolumn{2}{c}{ 95\% Confidence } \\
& & & \multicolumn{2}{c}{$\begin{array}{c}\text { Interval of the } \\
\text { Difference }\end{array}$} \\
5.187 & 72 & 0.000 & 8.73632 & 19.64206 \\
\hline
\end{tabular}

Dari uji normalitas diperoleh informasi bahwa nilai signifikansi (p-value) untuk kelas eksperimen dan kelas kontrol masing-masing adalah 0,2. Dengan menggunakan tingkat kepercayaan 95\% (signifikansi $\alpha=0,05$ ), maka nilai signifikansi hasil perhitungan lebih besar dari $\alpha$. Dengan demikian, dapat disimpulkan bahwa data $\mathrm{N}$-gain pada kelas eksperimen maupun kelas kontrol terdistribusi normal. Dari uji homogenitas diperoleh hasil bahwa variansi data memiliki signifikansi 0,262. Dengan menggunakan tingkat kepercayaan 95\% (signifikansi $\alpha=0,05$ ) maka nilai signifikansi hasil perhitungan lebih besar dari $\alpha$ sehingga dapat disimpulkan bahwa data $\mathrm{N}$-gain yang digunakan adalah homogen.

Uji statistik yang terakhir adalah uji hipotesis menggunakan uji t. Berdasarkan hasil pengolahan uji t diperoleh nilai signifikansi 0,0 (tepatnya 1,8 x 10-6) . Dengan menggunakan tingkat kepercayaan 95\% (signifikansi $\alpha=0,05$ ) maka nilai signifikansi hasil perhitungan uji $\mathrm{t}$ lebih kecil dari $\alpha$ sehingga hipotesis penelitian diterima. Dengan demikian, dapat ditegaskan bahwa pembelajaran di kelas eksperimen dengan mengimplementasikan discovery learning dapat lebih meningkatkan pemahaman konsep listrik dinamis.

Keunggulan discovery learning dalam meningkatkan keterampilan proses sains sangat dipengaruhi oleh langkah pembelajaran yang dilaksanakan oleh siswa. Kegiatan pembelajaran discovery learning aktif melibatkan siswa dalam kegiatan pembelajaran serta mampu menstimulus minat belajar siswa melalui demonstrasi fenomena yang dianggap aneh oleh siswa atau pun melalui kegiatan percobaan (Pratiwi, F., Hairida, A., Rasmawan, R., 2014). Berbeda halnya dengan pembelajaran konvensional dimana siswa lebih banyak mendengarkan penjelasan guru di depan kelas dan melaksanakan tugas jika guru memberikan latihan soal-soal, sehingga hasil belajar kurang baik (Sanjaya, W., 2008). Discovery learning juga dapat mengembangkan cara belajar siswa aktif dengan menemukan sendiri dan menyelidiki sendiri, sehingga akan diperoleh hasil yang akan setia dan tahan lama dalam ingatan serta tidak mudah dilupakan siswa (Hosna, 2014).

Pembelajaran dalam discovery learning memfasilitasi siswa untuk dapat berinteraksi dengan dengan alat peraga yang digunakan dalam kelas serta interaksi antar siswa dan guru serta melalui kegiatan diskusi yang memperkuat pemahaman siswa terhadap konsep. Jauhar menyatakan bahwa interaksi dengan lingkungan dapat memperbaiki pemahaman dan memperkaya pengetahuan (Jauhar, M., 2011). Slameto menegaskan bahwa pembelajaran dengan berdiskusi bersama siswa lain dapat 
meningkatkan pengetahuan dan ketajaman berpikir (Slameto, 2010).

Nursalim menyatakan bahwa belajar penemuan meningkatkan penalaran dan kemampuan berfikir untuk melatihkan keterampilanketerampilan kognitif yang digunakan untuk menemukan dan memecahkan masalah sehingga pembelajaran bermakna dapat terjadi. Melalui model discovery learning akan terjadi pembelajaran yang bermakna bagi siswa karena siswa terlibat secara aktif dalam proses pembelajaran untuk bereksperimen, meningkatkan kemampuan berpikir siswa untuk menemukan prinsip, konsep dan pemahamannya, siswa menjadi lebih mandiri, menumbuhkan inisiatif siswa belajar dalam kelompok dan bekerja sama dalam menyelesaikan tugas-tugas belajarnya (Mochamad, N., 2007).

Selanjutnya, menurut Brunner salah satu tujuan pembelajaran discovery learning adalah melatih keterampilan-keterampilan peserta didik untuk menemukan dan memecahkan masalah tanpa pertolongan orang lain dan meminta peserta didik untuk belajar menganalisis dan memanipulasi informasi (Dahar, R., 2011).

Secara rinci proses pembelajaran yang dilaktihkan dalam discovery learning ditunjukkan pada Tabel 8.

Dari keterampilan yang dilatihkan selama kegiatan pembelajaran dapat dilihat bahwa keterampilan mengkomunikasikan dilatihkan di setiap langkah pembelajaran, tetapi keterampilan mengkomunikaskan ini malah memiliki N-gain yang paling rendah dibandingkan yang lainnya. Hal ini terjadi akibat kegiatan pembelajaran diselenggarakan secara berkelompok sehingga siswa yang mempunyai kemampuan rendah cenderung untuk sulit mengutarakan pendapat mereka dan lebih senang untuk duduk sambil mendengarkan proses diskusi di dalam kelompok maupun dalam kelas sehingga ekspektasi dari kegiatan pembelajaran ini dapat terganggu oleh siswa yang terbiasa dengan pembelajaran tradisional (Sitiataya, P.).

\begin{tabular}{|c|c|c|}
\hline $\begin{array}{c}\text { Langkah } \\
\text { pembelajaran }\end{array}$ & $\begin{array}{c}\text { Aktivitas } \\
\text { peserta didik }\end{array}$ & $\begin{array}{c}\text { Keterampilan yang } \\
\text { dilatihkan }\end{array}$ \\
\hline $\begin{array}{l}\text { Mengumpul } \\
\text { kan } \\
\text { engalama } \\
\text { n siswa }\end{array}$ & $\begin{array}{l}\text { O Menjawab } \\
\text { pertanyaan } \\
\text { apersepsi } \\
\circ \text { Menjawab } \\
\text { pertanyaan } \\
\text { motivasi } \\
\text { (masalah) } \\
\text { o Menjawab } \\
\text { pertanyaan } \\
\text { konsepsi } \\
\text { awal } \\
\text { o Mengamati } \\
\text { fenomena } \\
\text { yang } \\
\text { ditunjukkan } \\
\text { dalam } \\
\text { demonstras } \\
\text { i }\end{array}$ & $\begin{array}{l}\text { Mengamati } \\
\text { Mengkomunikasikan }\end{array}$ \\
\hline $\begin{array}{l}\text { Membangun } \\
\text { konsep }\end{array}$ & $\begin{array}{l}\text { - Mengamati } \\
\text { fenomena } \\
\text { dalam } \\
\text { praktikum } \\
\text { - Melakukan } \\
\text { pengukura } \\
\text { n dengan } \\
\text { menggunak } \\
\text { an alat } \\
\text { ukur yang } \\
\text { sesuai } \\
\text { - Menjawab } \\
\text { pertanyaan } \\
\text { arahan }\end{array}$ & $\begin{array}{l}\text { Mengamati } \\
\text { Mengukur } \\
\text { Mengkomunikasikan }\end{array}$ \\
\hline $\begin{array}{l}\text { Menarik } \\
\text { kesimpulan }\end{array}$ & $\begin{array}{l}\text { - Menjawab } \\
\text { pertanyaan } \\
\text { arahan } \\
\text { - Membuat } \\
\text { kesimpulan }\end{array}$ & $\begin{array}{l}\text { Mengkomunikasikan } \\
\text { Membuat } \\
\text { kesimpulan }\end{array}$ \\
\hline
\end{tabular}




\section{KESIMPULAN}

Berdasarkan penelitian yang telah dilakukan mengenai implementasi discovery learning untuk meningkatkan keterampilan dasar proses sains dapat disimpulkan bahwa discovery learning dapat meningkatkan keterampilan dasar proses sains dengan katogori tinggi. Aspek keterampilan dasar sains dengan $\mathrm{N}$-gain terbesar dicapai pada aspek keterampilan mengamati

\section{DAFTAR PUSTAKA}

Badan Standar Nasional Pendidikan, "Panduan Penyusunan KTSP" Jakarta, Depdiknas, 2006.

C. Wenning, "The Levels of Inquiry Model of Science Teaching". Journal of Physics Teacher Education Online, vol. 6, no. 2, pp. 9-16, 2011.

Direktorat Tenaga Kependidikan, "Strategi Pembelajaran MIPA" Jakarta, Departemen Pendidikan Nasional, 2008.

F. Pratiwi, A. Hairida, dan R. Rasmawan, "Pengaruh penggunaan model discovery learning dengan pendekatan saintifik terhadap keterampilan berfikir kritis siswa SMA". Jurnal Pendidikan dan Pembelajaran, vol. 3, no.7, pp.6-18, 2014.

Hosna, . "Pendekatan Saintifik Dan Kontekstual Dalam Pembelajaran Abad 21", Bogor, Graha Indonesia, pp 280-285, 2014.

Kosasih, "Strategi belajar dan pembelajaran implementasi kurikulum 2013, Bandung, Yrama widya, 2014.

M. Yusuf, A. Ratna, "Penerapan Model Pembelajaran Discovery Learning Menggunakan Pembelajaran Tipe Shared dan Webbed untuk Meningkatkan Keterampilan Proses Sains", JPPPF - Jurnal
Penelitian \& Pengembangan Pendidikan Fisika, volume 1, no 2, pp 19-26, 2015.

M.Nenchi, E. Swistoro, and E. Risdianto, "Pengaruh model discovery learning dengan pendekatan saintifik terhadap keterampilan proses sains dan hasil belajar", Jurnal Pembelajaran Fisika, Vol. 1, No. 1, pp 142-147, 2017.

M. Jauhar, "Implementasi paikem dari behavioristiksampai konstrukti-vistik", Jakarta, Prestasi PustakaPublisher, pp. 8083, 2011.

N. Mochamad, "Psikologi Pendidikan", Surabaya, Unesa University Press. Pp. 63-67, 2007

R. Nuryani, S. Dirdjosoemarto, S. Yudianto, A. Achmad, Y. Subekti, R.. Rochintaniawati, D. Nurjhani, M. "Strategi Belajar Mengajar Biologi" Malang, UM Press, 2005, pp 8082.

R. Rezba, J. Sprague, C. Fiel, "Learning and Assesing Science Process Skills". Virginia, Kendal/Hunt Publishing Company, 2005.

R. Rizal. "Penerapan pendekatan demonstrasi interaktif untuk meningkatkan keterampilan dasar proses sains siswa". Gravity, vol. 3, no. 1, pp 40-50, 2017.

R. Rizal. "Implementation of discovery learning inimproving understanding of dynamic electric concept", jurnal siliwangi, vol 4, no. 1, 2018.

R. Dahar,"Teori-teori Belajar", Jakarta, Penerbit Erlangga. Pp. 94-95, 1989.

R. Dahar, "Teori-teori Belajar \& Pembelajaran”,Jakarta, Erlangga, pp 7275,2011

R. Hake, "Relationship of Individual Student Normalized Learning Gains in Mechanic 
with Gender, High-School Physics, and Pretest Scores on Mathematics and Spatial Visualization", 2002.

S. Sukmadinata, "Metode penelitian pendidikan", Bandung, PT Remaja Rosdakarya, 2009.

S. Arikunto, "Dasar-dasar Evaluasi Pendidikan", Jakarta, Bumi Aksara, 2003.

W. Sanjaya, "Strategi pembelajaran berorientasi standar proses pendidikan", Jakarta, Prenada Media. pp70-72, 2008.

Slameto, "Strategi belajar mengajar", Jakarta , Rhineka cipta, 2010.

P. Sitiatava, "Desain Belajar Mengajar Kreatif Berbasis Sains", Jogjakarta, DIVA Press, pp 107-108, 